MARJANA ČUBRANIĆ-DOBRODOLAC, M.Sc. ${ }^{1}$

(Corresponding author)

E-mail: marjana@sf.bg.ac.rs

KRSTO LIPOVAC, Ph.D. ${ }^{1}$

E-mail:k.lipovac@sf.bg.ac.rs

SVETLANA ČIČEVIĆ, Ph.D. ${ }^{1}$

E-mail: s.cicevic@sf.bg.ac.rs

BORIS ANTIĆ, Ph.D. ${ }^{1}$

E-mail: b.antic@sf.bg.ac.rs

${ }^{1}$ University of Belgrade,

Faculty of Transport and Traffic Engineering

Vojvode Stepe 305, 11000 Belgrade, Serbia
Human - Transport Interaction

Preliminary Communication

Submitted: 21 Mar. 2017

Accepted: 4 Oct. 2017

\title{
A MODEL FOR TRAFFIC ACCIDENTS PREDICTION BASED ON DRIVER PERSONALITY TRAITS ASSESSMENT
}

\begin{abstract}
The model proposed in this paper uses four psychological instruments for assessing driver behaviour and personality traits aiming to find a relationship between the considered constructs and the occurrence of traffic accidents. $A$ Barratt Impulsiveness Scale (BIS-11) was used for the assessment of impulsivity, Aggressive Driving Behaviour Questionnaire $(A D B Q)$ for assessing the aggressiveness while driving, Manchester Driver Attitude Questionnaire (DAQ) and the Questionnaire for self-assessment of driving ability. Besides these instruments, the participants filled out an extensive demographic survey. Within the statistical analysis, in addition to the descriptive indicators, correlation coefficients were calculated and four hierarchical regression analyses were performed to determine the predictive power of personality traits on the occurrence of traffic accidents. Further, to confirm the results and to obtain additional information about the relationship between the considered variables, the structural equation modelling and binary logistic regression have been implemented. A sample of this research covered 305 drivers, of which there were 100 bus drivers and 102 truck drivers, as well as 103 drivers of privately owned vehicles. The results indicate that BIS-11 and $A D B Q$ questionnaires show the best predictive power which means that impulsivity and aggressiveness as personality traits have the greatest influence on the occurrence of traffic accidents. This research could be useful in many fields, such as the design of selection procedures for professional drivers, development of programs for the prevention of traffic accidents and violations of law, rehabilitation of drivers who have been deprived of the driving license, etc.
\end{abstract}

\section{KEY WORDS}

risk perception; aggressiveness; impulsiveness; self-perception; traffic accidents; traffic safety;

\section{INTRODUCTION}

A human is the most important and also the most complex factor in traffic safety. When participating in traffic, the driver is expected to possess adequate abilities, knowledge and skills and to perform safe driving manoeuvres. The lack of any of these elements can lead to making the mistakes which can result in a traffic accident. When it comes to the analysis of dominant personality traits of the drivers, many studies have shown a strong connection between risk perception and involvement in accidents. By understanding the factors of accidents related to the driver risk assessment, the ability to define adequate measures increases which should reduce the negative consequences of inappropriate behaviour.

The most common circumstances leading to the occurrence of accidents are excessive speed, incorrect assessment of the traffic situation, performance of improper actions, as well as the psychophysical condition of the driver [1, 2]. This indicates the importance of studying the nature of risky behaviour of drivers in order to take appropriate measures to increase the traffic safety.

Since the data on the impact of risk propensity of drivers are often inaccessible in the police reports about accidents, during recent years in the field of traffic safety particular attention has been focused on the drivers' attitudes. In this way, generalized conclusions are made about the personality traits which may have a predictive value in the occurrence of traffic accidents. The attitudes are one of the factors which influence the behaviour in traffic. There is a common viewpoint that attitudes affect traffic safety more than competencies. There are a number of drivers who are aware that certain behaviour is unsafe or illegal, but they have a wrong attitude and believe their inappropriate behaviour will not affect them or other people in traffic.

The personality traits have been found to correlate with risk perception of various road hazards; however, only weakly to moderately. In the study which is primarily focused on risk perception, Sjöberg and Wahlberg [3] obtained the result that personality traits are 
significant predictors in risk perception while driving. Other researchers have focused their studies on the explanation of risk perception in the occurrence of traffic accidents $[4,5]$.

In the studies analysing data on accidents in developed countries, behaviour which could be classified as aggressive is considerably present [6, 7, 8, 9]. Driver aggression involves behaviour such as driving at excessive speed, improper following, improper lane changing and passing, intimidation of other road users, drink-driving and drug-driving offences, verbal outbursts and gestures aimed at other drivers, etc. Numerous studies have shown a high predictive power of aggressiveness in explaining the occurrence of traffic offences and even traffic accidents $[10,11,12,13$, $14,15,16,17]$.

Besides aggression, it is important to mention some other phenomena which involve similar behaviour. Due to similarity, these phenomena are often equalized in the analysis of inappropriate actions in driving. For this study it is of particular importance to mention the impulsiveness which, although belong ing to the congenital traits, indicates similar forms of behaviour as aggressiveness. For this reason, numerous studies have been launched with the intention of establishing a relation between the dimensions of these behaviours. Some results show that high impulsiveness is associated with future inappropriate social behaviour, including aggression [18, 19]. High scores on the Barratt Impulsiveness Scale (BIS), as well as on the Buss-Durkee Hostility Inventory (BDHI) scale, showed a significant correlation with sudden outbursts of aggressive behaviour [20]. Some results showed that high impulsivity is associated with aggressive and transgressive driving [21]. The latest version of the questionnaire BIS, BIS-11 showed a significant relationship between impulsiveness and aggressiveness. In a study involving students the results showed that those who achieved a distinct score on the BIS-11 scale, often demonstrated involvement in a risky behaviour, including the use of alcohol / drugs and aggression [20]. When testing the impulsiveness and its relation to aggressiveness, some researchers have focused on the differences between reactive and proactive aggression [22]. In these studies, reactive aggression is considered to be an angry or defensive behaviour in response to perceived provocation or frustration. On the other hand, proactive aggression is deliberately controlled in order to achieve the desired aim. After this differentiation, the researchers concluded that impulsiveness correlates with reactive aggression, especially in males.

In this paper, the main topic of research is the investigation of the influence of different personality traits such as impulsiveness, aggressiveness while driving, attitude toward risk propensity and self-assessment of driver ability on the occurrence of traffic accidents. The conclusions are derived by using the standardized measuring instruments and implementing the hierarchical regression analysis to determine the proportion of variance in explaining the occurrence of traffic accidents for each of the observed phenomenon. Structural equation modelling and binary logistic regression is implemented to confirm the results of hierarchical regression analysis.

The aim was to propose an original model of driver behaviour which will recognize as a result the drivers who are prone to committing traffic accidents. The initial motive of the authors was to test which of the applied instruments would be the most suitable in practice for driver testing in different situations such as a selection of professional drivers, young drivers training, programs for drivers deprived of driving license, programs for the prevention of accidents, etc. In the mentioned testing it would be possible to detect a propensity toward experiencing traffic accidents and by this to improve road safety.

The research on the relationship between four psychological instruments for assessing driver behaviour and personality traits and occurrence of traffic accidents was carried out on the representative sample which is composed of drivers of different categories: bus drivers, truck drivers, and drivers of privately owned vehicles. This diversification makes the obtained conclusions more reliable. Among others, in the sample there were bus drivers working in the largest company for intercity transportation and also truck drivers from the largest freight transportation company in the country. On the other hand, the majority of previous studies considered students as drivers, or just a certain category of drivers or driver offenders.

\section{SURVEY METHODOLOGY}

In this section the following will be described: the sample, research instruments or questionnaires, survey data collection techniques, research procedure, as well as the implemented statistical measures.

\subsection{Used instruments}

In the study, in addition to the demographic questionnaire, four questionnaires for assessing the personality traits were used: Barratt Impulsiveness Scale, Aggressive Driving Behaviour Questionnaire, Manchester Driver Attitude Questionnaire and Questionnaire for Self-Assessment of Driving Ability.

The demographic questionnaire consisted of the most relevant questions on the demographic characteristics of respondents. The issues related to gender, age, driving experience, annual mileage driven, the number of past accidents, as well as the category of vehicles which the respondent operates were considered. The type of multiple choice questions was used with sufficiently detailed categories offered. 
Barratt Impulsiveness Scale (BIS-11) is an instrument for the assessment of impulsivity as a personality trait. In this research we used a version of BIS-11 constructed by Patton [19]. The questionnaire consists of 30 questions which cover a variety of situations and aspects characteristic for impulsive behaviour and habits of impulsive behaviour. The respondents were expected, by using the 4-point Likert scale, to estimate how often they agreed with the statements which describe the most representative impulsive habits and practices. The scaled responses correspond to the following statements: from 1=Never/rarely to 4=Always/ almost always. For certain questions in the questionnaire, the inversion of the response values were made.

Aggressive Driving Behaviour Questionnaire (ADBQ) was designed by Mouloua [23]. The intention of the researchers in the design of this questionnaire was to create an instrument with good predictive power considering aggressive situations which are typical in driving. These vary in the range from gestures directed toward other drivers, to explicit aggressive outbursts, such as passing through a red light at an intersection. The instrument contains 20 questions. The respondents were asked to assess the likelihood of manifestation of aggressive driving using the 6-point scale. Results are given in the range of $1=$ Never to $6=$ Almost always.

Manchester Driver Attitude Questionnaire (DAQ) is a questionnaire for the assessment of attitudes toward risk propensity while driving constructed by Parker [24]. The questionnaire consists of 20 questions with a scale of answers from $1=$ Strongly Disagree to $5=$ Strongly Agree. Most questions refer to the typical traffic situations which can be characterized as highrisk ones. DAQ includes statements relating to speeding, drink-driving, close-following, and dangerous overtaking. We arranged the scores in the way that higher scores correspond to higher risk propensity while driving. Scores of subjects can range from 20 to 100 points.

Questionnaire for self-assessment of driving ability was developed by Tronsmoen [25]. It is an inventory of statements about how the drivers react in certain traffic situations. Based on the responses, it is possible to obtain the information about what picture the respondents create about themselves as drivers. There are 22 questions and answers in the form of 4-point Likert scale. Answers ranged from 1=Never/up to 4=Always/ almost always. Higher score on the test corresponds to a better evaluation of one's own driving abilities.

\subsection{Sample and research procedures}

The observed sample consisted of 305 drivers of both genders, different education and aged between 18 and 69 years. The sample was heterogeneous in terms of the length of driving experience and frequency of driving. Among professional drivers, the most numerous were truck drivers, 102 of them were in the sample. Then, the study also included 100 bus drivers working on the regular intercity lines. Finally, the 103 drivers of privately owned vehicles who met the requirements for the participation in this research accepted to answer all the questions.

At the start of testing the respondents were asked to voluntarily and honestly participate in interviewing. They were explained the anonymous nature of the research and the fact that the collected answers will be used only for the scientific purposes.

\subsection{Statistical analysis and methods}

Data were analysed using the Statistical Package for Social Scientists (SPSS) version 17 and AMOS 6.0. In addition to the descriptive statistics and determination of the correlation coefficients, to design a model of driver behaviour the hierarchical regression analysis was used. To construct the model which explains what impacts an occurrence of traffic accident, four hierarchical regression analyses were performed. In this procedure we considered the results of overall achievement scores for the following measuring instruments: BIS-11 questionnaire for the assessment of impulsivity, AQBD questionnaire for assessing the aggressiveness in driving, DAQ questionnaire for assessment of attitudes towards major driving issues which can be classified as attitudes toward risk propensity, as well as the questionnaire for self-assessment of driving ability. The authors' intention was to examine whether some of the traffic safety indicators (primarily referring to the tendency toward experiencing accidents) can be predicted on the basis of stable or less stable psychological constructs. The obtained results are tested by structural equation model and binary logistic regression. The binary logistic regression has considered all four psychological instruments together in the same model.

\section{RESULTS}

The sample consisted primarily of men (88\%). This gender distribution is expected since the largest number of professional drivers are males due to the hard nature of this job. Considering the number of traffic accidents reported by drivers in demographic questionnaire, it can be concluded that $56.8 \%$ of examined drivers were involved in traffic accidents at least once. This rate is higher than expected, having in mind for example that there were 35,971 traffic accidents in Serbia in the year 2016 [26], which means that there was approximately 1 accident per 194 inhabitants annually. A possible explanation for such a high accident rate could be, besides the fact that usually more people participate in one accident and also that all accidents are not officially reported, that two-thirds of the 
sample are professional drivers who are on the road around 8 hours or more almost every day and most of them from the sample have the driver's experience of over 20 years. Higher accident rate is particularly contributed by their hard working conditions [27].

Figure 1 shows that the highest percentage of drivers are distributed in the category which experienced between 1 and 3 accidents (43.6\%). The number of reported traffic accidents could be taken as an indicator of risk preferences and attitude towards road safety. A relationship between this variable and various types of driving behaviour is scrutinized in this research.

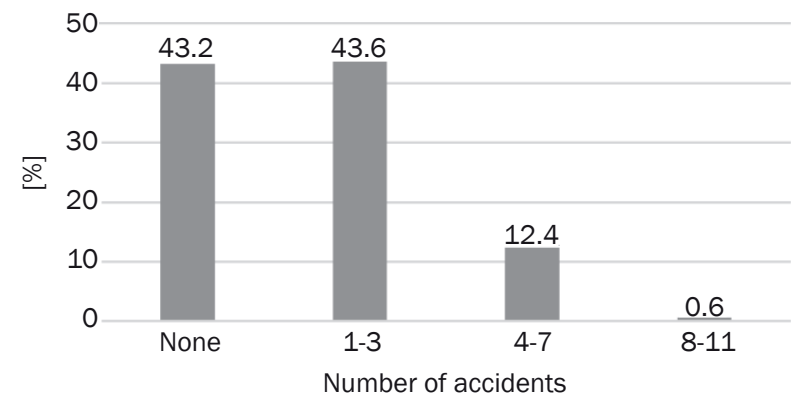

Figure 1 - Percentage distribution of the total number of traffic accidents

\subsection{Hierarchical regression analysis}

To analyse the relationship between experiencing traffic accidents and the observed characteristics of the driver, the hierarchical regression analysis was conducted. The statistical procedure was carried out in blocks with control variables the age and driving experience which can affect the overall obtained results. To determine the assumed impact of these variables on the experience of traffic accidents, first the Pearson correlation coefficients were analysed. Table 1 shows the connection between variables age and driving experience with the number of accidents which respondents had in their driving history. Also, Table 1 shows the connection with psychological constructs measured by questionnaires and expressed as total scores. Here it is possible to observe the existence of a significant connection of medium intensity between age and driving experience with involvement in traffic accidents. Since the statistically significant correlations were identified in this analysis, the variables age and driving experience are defined as control variables in constructing the regression model of drivers' behaviour. The correlation coefficients between psychological constructs and traffic accidents will be used to discuss the obtained results of implemented models in this paper.

Prediction of traffic accidents considering drivers impulsivity (Regression model I)

To create behaviour pattern I, in the first block of hierarchical regression analysis the total number of traffic accidents which drivers experienced during their driving history was set as a dependent variable. At the same time, the variables age and driving experience were introduced as independent variables. In the second block of hierarchical regression analyses the achieved overall score in BIS-11 questionnaire is included as the next independent variable.

In this regression model (Regression model I), the variables age and driving experience, included in the first block, account for $17.4 \%$ of variance in the occurrence of traffic accidents $(F(2,302)=31.729$, $p<0.001)$. After the introduction of impulsiveness (Table 2), the regression model describes $38.3 \%$ of the observed variance $(F(3,301)=62.192, p<0.001)$. The impulsiveness through the overall obtained score explains additional $20.9 \%$ of variance of the number of experienced traffic accidents, even when the detected

Table 1 - Pearson correlation coefficients

\begin{tabular}{|c|c|c|c|c|c|c|c|}
\hline Variable & 1 & 2 & 3 & 4 & 5 & 6 & 7 \\
\hline $\begin{array}{l}\text { Age } \\
\text { Sig.(2-tailed) }\end{array}$ & - & & & & & & \\
\hline $\begin{array}{l}\text { Driving experience } \\
\text { Sig.(2-tailed) }\end{array}$ & $\begin{array}{l}0.354 * * \\
0.000\end{array}$ & - & & & & & \\
\hline $\begin{array}{l}\text { Involvement in traffic } \\
\text { accidents } \\
\text { Sig.(2-tailed) }\end{array}$ & $\begin{array}{l}0.365 * * \\
0.000\end{array}$ & $\begin{array}{l}0.375 * * \\
0.000\end{array}$ & - & & & & \\
\hline $\begin{array}{l}\text { ADBQ } \\
\text { Sig.(2-tailed) }\end{array}$ & $\begin{array}{l}0.118^{*} \\
0.039\end{array}$ & $\begin{array}{l}0.173 * * \\
0.002\end{array}$ & $\begin{array}{l}0.521 * * \\
0.000\end{array}$ & - & & & \\
\hline $\begin{array}{l}\text { BIS-11 } \\
\text { Sig.(2-tailed) }\end{array}$ & $\begin{array}{l}0.219 * * \\
0.000\end{array}$ & $\begin{array}{l}0.241 * * \\
0.000\end{array}$ & $\begin{array}{l}0.546 * * \\
0.000\end{array}$ & $\begin{array}{l}0.270 * * \\
0.000\end{array}$ & - & & \\
\hline $\begin{array}{l}\text { DAQ } \\
\text { Sig.(2-tailed) }\end{array}$ & $\begin{array}{l}0.032 \\
0.581 \\
\end{array}$ & $\begin{array}{l}0.180 * * \\
0.002\end{array}$ & $\begin{array}{l}0.339 * * \\
0.000\end{array}$ & $\begin{array}{l}0.253 * * \\
0.000\end{array}$ & $\begin{array}{l}0.189 * * \\
0.001\end{array}$ & - & \\
\hline $\begin{array}{l}\text { Self-assessement } \\
\text { Sig.(2-tailed) }\end{array}$ & $\begin{array}{r}-0.051 \\
0.379 \\
\end{array}$ & $\begin{array}{l}0.065 \\
0.258 \\
\end{array}$ & $\begin{array}{l}-0.249 * * \\
0.000 \\
\end{array}$ & $\begin{array}{l}-0.115^{*} \\
0.045 \\
\end{array}$ & $\begin{array}{l}-0.130 * \\
0.023 \\
\end{array}$ & $\begin{array}{l}0.008 \\
0.894 \\
\end{array}$ & - \\
\hline
\end{tabular}

$\star p<0.05, * \star p<0.01$ 
Table 2 - The results of Regression model I

\begin{tabular}{|c|c|c|c|c|c|c|c|c||}
\hline \hline Model & $\mathrm{R}^{2}$ & $\mathrm{R}^{2}$ change & $\mathrm{F}$ & Sign. & $\mathrm{B}$ & $\beta$ & $\mathrm{t}$ & Sig. \\
\hline \hline $\mathrm{a}$ & 0.174 & 0.174 & 31.729 & 0.000 & \multirow{2}{*}{0.052} & \multirow{2}{*}{0.477} & \multirow{2}{*}{10.095} & \multirow{2}{*}{0.000} \\
$\mathrm{~b}$ & 0.383 & 0.209 & 62.192 & 0.000 & & \\
\hline
\end{tabular}

a. Predictors: (Constant), Driving experience, Age

b. Predictors: (Constant), Driving experience, Age, BIS-11 total

c. Dependent Variable: Total number of traffic accidents

impact of age and driving experience is statistically removed $(F(1,301)=101.912, p<0.001)$. The values of $F$ indicate that this model significantly improves the ability to predict the dependant variable.

The variable impulsiveness gives a statistically significant unique contribution to this equation and further relationship is described by the following coefficients: $\beta=0.477, t=10.095, p<0.001$. By conducting the t-test a conclusion can be made about the significance of beta coefficient. Since the $p$ value is lower than 0.05 , this means that beta coefficient is statistically significant. Further, the smaller the value of $p$ and the larger the value of $t$ bring to a greater contribution of the considered predictor.

The variables age of the driver and driving experience, according to the preliminary expectations explain a significant portion of the variance in the occurrence of traffic accidents. However, even if the impact of these demographic variables is removed, the impulsiveness, as a measure of the overall achievement of the respondents in the BIS-11 questionnaire, still significantly contributes to the explanation of variance in the number of experienced accidents.

Prediction of traffic accidents considering the aggressiveness of drivers (Regression model II)

In Regression model II an independent variable was the same as in the previous case (the total number of accidents). Age and driving experience as control variables for which the relation with traffic accidents was previously explained are included in the first block of regression. In the second block the overall aggressiveness in driving expressed through the achieved score is included with the aim of explaining the importance of aggressive behaviour of drivers in the occurrence of traffic accidents (by the controlling variables age and driving experience).

In this hierarchical regression analysis, the variables age and driving experience, introduced in the first block, as in model I, account for $17.4 \%$ of variance in the occurrence of traffic accidents $(F(2,302)=31.729$, $p<0.001)$. After the introduction of aggression score in the equation all variables jointly describe $36 \%$ of the total variance $(F(3,301)=56.320, p<0.001)$. Driver aggression, seen through the total score on the questionnaire describes the additional $18.6 \%$ of the variance of involvement in traffic accidents $(F(1,301)=87.355$, $\mathrm{p}<0.001)$. The results are shown in Table 3. The values of $\mathrm{F}$ indicate that this model also significantly improves an ability to predict the dependant variable. Statistical significance was identified for the variable aggression and it is expressed through the following coefficients: $\beta=0.439, t=9.346, p<0.001$ ).

Prediction of traffic accidents considering the attitudes toward risk propensity of drivers (Regression model III)

A procedure of hierarchical regression analysis in model III is the same as in the previous two cases, as well as the independent and control variables which are entered into the equation at the beginning. In the second block the overall performance on Manchester driver attitude questionnaire for risk assessment was considered (Table 4) as an independent variable.

Table 3 - Results of Regression model II

\begin{tabular}{|c|c|c|c|c|c|c|c|c||}
\hline \hline Model & $\mathrm{R}^{2}$ & $\mathrm{R}^{2}$ change & $\mathrm{F}$ & Sign. & $\mathrm{B}$ & $\beta$ & $\mathrm{t}$ & Sig. \\
\hline \hline $\mathrm{a}$ & 0.174 & 0.174 & 31.729 & 0.000 & \multirow{2}{*}{0.033} & \multirow{2}{*}{0.439} & \multirow{2}{*}{9.346} & \multirow{2}{*}{0.000} \\
$\mathrm{~b}$ & 0.360 & 0.186 & 56.320 & 0.000 & & & \\
\hline
\end{tabular}

a. Predictors: (Constant), Driving experience, Age

b. Predictors: (Constant), Driving experience, Age, ADBQ total

c. Dependent Variable: Total number of traffic accidents

Table 4 - Results of Regression model III

\begin{tabular}{|c|c|c|c|c|c|c|c|c||}
\hline Model & $\mathrm{R}^{2}$ & $\mathrm{R}^{2}$ change & $\mathrm{F}$ & Sign. & $\mathrm{B}$ & $\beta$ & $\mathrm{t}$ & Sig. \\
\hline \hline $\mathrm{a}$ & 0.174 & 0.174 & 31.729 & 0.000 & \multirow{2}{*}{0.022} & \multirow{2}{*}{0.285} & \multirow{2}{*}{5.621} & \multirow{2}{*}{0.000} \\
$\mathrm{~b}$ & 0.252 & 0.079 & 33.829 & 0.000 & & & \\
\hline
\end{tabular}

a. Predictors: (Constant), Driving experience, Age

b. Predictors: (Constant), Driving experience, Age, DBQ total

c. Dependent Variable: Total number of traffic accidents 
Table 5 - Results of Regression model IV

\begin{tabular}{|c|c|c|c|c|c|c|c|c||}
\hline Model & $\mathrm{R}^{2}$ & $\mathrm{R}^{2}$ change & $\mathrm{F}$ & Sign. & $\mathrm{B}$ & $\beta$ & $\mathrm{t}$ & Sig. \\
\hline \hline $\mathrm{a}$ & 0.174 & 0.174 & 31.729 & 0.000 & -0.016 & -0.263 & -5.211 & 0.000 \\
$\mathrm{~b}$ & 0.242 & 0.068 & 32.037 & 0.000 & & & \\
\hline
\end{tabular}

a. Predictors: (Constant), Driving experience, Age

b. Predictors: (Constant), Driving experience, Age, Self-assessment total

c. Dependent Variable: Total number of traffic accidents

In the case of Regression model III, the values of the control variables are repeated and account for $17.4 \%$ of the observed variance $(F(2,302)=31.729$, $\mathrm{p}<0.001)$. In the second block, by inclusion of the total risk score, all variables define about $25.2 \%$ of the total variance $(F(3,301)=33.829, p<0.001)$. Attitudes toward risk situations, expressed by the total score on the questionnaire describe an additional $7.9 \%$ of the variance of involvement in traffic accidents $(F(1,301)=31.597, p<0.001)$. The share of total risk in explaining the variance of traffic accidents is significantly lower than registered for the previously analysed forms of behaviour; however, the values of $F$ indicate that this model also significantly improves the ability to predict the dependant variable. The values which describe the intensity of a relationship are the following: $\beta=0.285, t=5.621, p<0.001$ ).

Prediction of traffic accidents considering self-assessment of driving ability (Regression model IV)

In the fourth regression analysis the independent variable was the same as in the previous cases (the total number of accidents). Age and driving experience as control variables are included in the first block of regression. In the second block the total score of self-assessment of driving ability is included. The aim was to explain what the significance of self-assessment that drivers make about their own skills and competencies is.

In Regression model IV, the variables age and driving experience, introduced in the first block account for $17.4 \%$ of variance in the occurrence of traffic accidents $(F(2,302)=31.729, p<0.001)$. After having introduced the score for self-assessment of driving ability in the equation, the model explains about $24.2 \%$ of the total variance $(F(3,301)=32.037, p<0.001)$. The driver's self-assessment, considered through the total score on the questionnaire, describes additional 6.8\% of the variance of involvement in traffic accidents $(F(1,301)=27.155, p<0.001)$. The results are shown in Table 5. It can be concluded that this model also significantly improved the ability to predict the dependent variable. However, the independent variable total score of self-assessment shows a negative relationship: $\beta=-0.263, t=-5.211, p<0.001$.

\subsection{Structural equation model}

Structural equation modelling (SEM) is a multivariate statistical analysis technique that is used to analyse the relationships between considered variables.
It can be viewed as a combination of factor analysis and regression or path analysis. Structural equation modelling is also known as second-generation method since it can be used to confirm the validity of so-called first-generation statistical methods such as correlation analysis, multiple regression, exploratory factor analysis, ANOVA, canonical correlation analysis. The latter are special cases of the former, and common SEM programs can be used to perform most classical statistical analyses if desired. The implementation of SEM brings some benefits compared to first-generation statistical methods. One of them is that it is possible to take into account random or measurement error in indicators, and even systematic or method error which could occur in the first-generation procedures [28].

In this paper SEM was used to test if the proposed model that uses the hierarchical regression analyses is valid. Here is also the aim to determine the association between the total scores on considered questionnaires and traffic accidents. As a result, we should be in a position to rank the predictor variables according to the intensity of impact on the occurrence of traffic crashes. For this purpose, the calculations were performed by using the Amos 6.0 software. The results for this model are shown in Figure 2. The standardized regression coefficients for all the pathways can be noticed. These results confirm the previously established conclusions in the hierarchical regression analysis where the following coefficients were obtained $\beta=0.477, \beta=0.439$, $\beta=0.285$ and $\beta=-0.263$, respectively. This means that the impulsiveness has the strongest connection with the occurrence of traffic accident $(\beta=0.41)$, followed

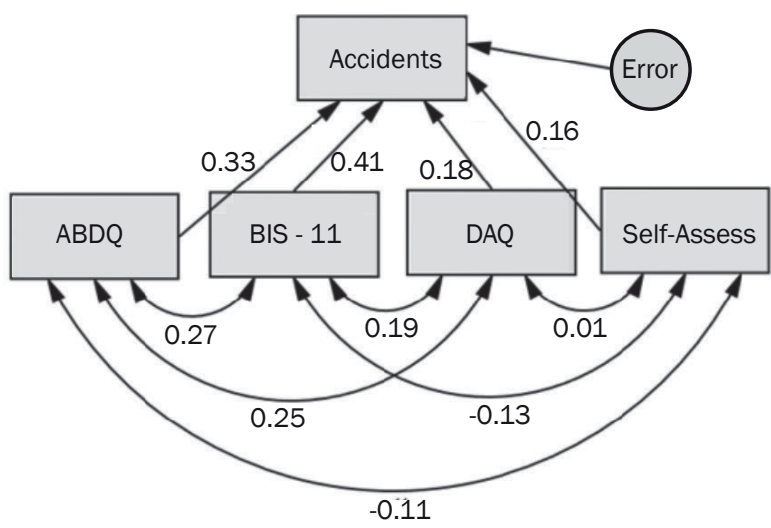

Figure 2 - Path diagram for ADBQ, BIS-11, DAQ and Selfassessment of driving ability and traffic accidents 
by aggressiveness $(\beta=0.33)$ and attitudes toward risk while driving ( $\beta=0.18)$. The self-assessment of driving ability records a negative correlation $(\beta=-0.16)$ which corresponds with the expectations. Figure 2 also represents the values of covariance describing an association between the observed variables.

\subsection{Application of binary logistic regression}

In order to obtain even more accurate cognition about the impact of psychological characteristics on the occurrence of traffic accidents, a binary logistic regression is applied. The dichotomous dependent variable is related to the (non)participation in accidents reported by the drivers in the questionnaire. The first category includes the respondents who had not experienced accidents in their driving history, while the second category concerns drivers who reported accidents (regardless of the number). The scores obtained on four instruments for assessing driving behaviour and personality traits (DAQ, BIS-11, ADBQ and Self-Assessment of Driving Ability) are used as independent predictor variables in the analysis. For each of the mentioned instruments, the drivers were segmented in three groups depending on the value of achieved score: low, medium and high.

The model with all the predictors proved to be statistically significant $\left(\chi^{2}=125.111 ; \mathrm{df}=4\right.$; sig. $=0.000$; $\mathrm{p}<0.001$ ) which means that the model makes a difference between the drivers who experienced traffic accidents and the ones who did not, and makes correct classification in $77.4 \%$ of cases. From Table 6 it can be concluded that the variables which significantly contribute to the predictive power of the model are those related to $\mathrm{DAQ}, \mathrm{ADBQ}$ and $\mathrm{BIS}-11$, while the instrument for self-assessment of driving ability does not show a statistically significant contribution to the model. B coefficients are positive for all the instruments except for the instrument that measures self-assessment of driving ability, which is in line with the results obtained in the previous chapter dealing with the hierarchical regression analysis. The negative $\mathrm{B}$ coefficient indicates that increasing the value of an independent variable (higher self-assessment score) results in a reduction of the probability of experiencing traffic accidents. In column named Exp (B), there are values which indicate the probability ratio distribution of each independent variable. In the concrete case, they indicate the following:
- The probability that a person will experience (or has already experienced) an accident is 4.16 times higher for the driver from any subsequent group (with higher scores) of the overall aggressiveness score;

- The probability that an individual will experience (or has already experienced) an accident is $\mathbf{5 . 9 4}$ times higher for the driver from any subsequent group (with higher scores) of the overall impulsiveness score;

- The probability that a person will experience (or has already experienced) an accident is 2.7 times higher for the driver from any subsequent group (with higher scores) of the overall score in assessing attitudes towards risky forms of behaviour in traffic.

\section{DISCUSSION AND CONCLUSION}

By considering $\beta$ coefficients obtained in the hierarchical regression analysis and confirmed by the correlation coefficients from Table 1, structural equation model and binary logistic regression, it can be noticed that the impact of impulsiveness on the occurrence of traffic accidents is the highest, followed by aggressiveness (with relatively similar values of $\beta$ coefficient), while $\beta$ coefficients in the case of attitudes toward risk and driving ability self-assessment are considerably lower (with relatively similar values among themselves).

The results of hierarchical regression analyses indicate that high scores on the impulsiveness scale BIS-11 and the scale of aggressive behaviour in driving ADBQ, form a less safe driving style expressed through higher probability of experiencing traffic accidents. Both scales explain a similar proportion of variance in the occurrence of accidents, even when the demographic variables, age and driving experience, are excluded. Although the contribution of all predictors in the hierarchical regression are statistically significant, it may be discussed if their levels are high or low. Here it should be kept in mind that it is difficult to predict some phenomenon based on the psychological instruments, especially if there is a single psychological trait in the model in relation to the occurrence of traffic accident which is a relatively rare event in the driving history of a person. Additionally, besides the stable psychological characteristics of personality and sensory-motor abilities, there are other factors which may affect the occurrence of accident such as: current

Table 6 - Results of binary logistic regression

\begin{tabular}{||l|c|c|c|c||}
\hline \multicolumn{1}{|c|}{ Variable } & B & Sig. & Exp(B) & 95\% C.I. for EXP(B) \\
\hline \hline ADBQ & 1.427 & 0.000 & 4.168 & 2.559 to 6.787 \\
\hline BIS-11 & 1.782 & 0.000 & 5.941 & 3.245 to 10.877 \\
\hline DAQ & 1.008 & 0.000 & 2.740 & 2.080 to 4.470 \\
\hline Self-assessment & -0.223 & 0.395 & 1.250 & 0.747 to 2.092 \\
\hline
\end{tabular}


psycho-physical conditions of the driver related to stress, fatigue, opiates, then the characteristics of the roads, as well as the characteristics of the vehicle itself operated by the driver. Therefore, the obtained value of $\mathrm{R}^{2}$ change could be considered as high, especially if it is compared with the results of other relevant studies with similar methodology where the obtained values are similar or lower [29, 30, 31].

Considering BIS-11 and ADBQ, the results can be interpreted through the prism of personality traits and dimensions of behaviour which these two instruments estimate and which are similar to a large extent. This similarity is confirmed by the structural equation model (Figure 2) having in mind the highest value of covariance (0.27). Thus, as it has already been discussed in the introduction, it is very difficult to separate the behavioural manifestations of these two phenomena.

When it comes to the instruments for DAQ and self-assessment of driving ability, they have a similar impact on the occurrence of traffic accidents. A proportion of variance in explanation of the dependent variable is almost identical in both cases. However, based on the value of covariance (0.01), the structural equation model showed that there is no strong direct relationship between these two instruments. It is important to explain the negative values of the standardised regression coefficients for the self-assessment of the driving ability instrument. The reason for obtaining such values lies in the fact that good result on the test is related to good self-assessment of driving ability which in our case turned out to be the correct measure of safe behaviour in traffic (reflected in the number of experienced accidents). The same explanation could be used for describing the negative values of covariance between self-assessment of driving ability and aggressiveness or impulsiveness (-0.11 and -0.13 , respectively).

Considering the predictive power of each of the implemented instruments for the assessment of individual behaviour, it is useful to have in mind the results of previous research where scientists used these instruments as tools for assessment.

First, BIS-11 instrument was used to assess the impact of general impulsiveness on traffic accidents. It is possible to conclude that this instrument which is often used in literature, showed a surprisingly high level of predictability in the explanation of accidents in the proposed model. This finding is particularly important in the field of traffic psychology where the stable dispositions of personality, especially in the past, rarely appeared as a reliable indicator of the occurrence of traffic accidents. Some of the most important results from the research where BIS-11 instrument was used to predict the behaviour of drivers are the following: Dahlen et al. [32] found a slight association between impulsivity scores and smaller penalties which students get for inappropriate behaviour. Then, Ryb et al. [33] found that higher scores on the questionnaire correlate with the behaviour such as not fastening a seat belt in the car, driving under the influence of alcohol, excessive speed, but also with involvement in traffic accidents. This result is in accordance with the findings of our research. The most recent results are presented by Moan et al. [34] who verified previous findings according to which the risky behaviour in driving is caused by the increased level of impulsiveness among drivers. On the other hand, some studies failed to find such a stable link between impulsiveness and risky behaviour in traffic $[35,36]$.

Considering Regression model II, which indicates a good predictive power of ADBQ questionnaire for evaluation of aggressive driving behaviour, it is possible to conclude that the construction of this model offers a significant result. This result could lead to the introduction of this relatively new instrument, or some similar ones which examine the same tendencies in driver behaviour, in various fields of application such as testing the drivers, their training, selection of professional drivers and even special programs for drivers temporarily deprived of the driving license. The proposed model is supported by the results of similar studies related to the consideration of aggressiveness in the function of unsafe driving behaviour. Most of these studies found that aggressive drivers are prone to risky behaviour and lighter or heavier traffic accidents compared to drivers with low aggressiveness. Considering the questionnaires used in these occasions it is useful to mention those which showed the greatest predictive character in describing unsafe behaviour. The most important results are obtained by the researchers who used the following measuring instruments for the assessment of aggressiveness in driving in general or through a specific dimension in the form of individual items: Driver Behaviour Questionnaire - DBQ [24], Driving Anger Expression Inventory - DAEI [37, 38], Driver's Angry Thoughts Questionnaire - DATQ [39], Driving Anger Scale - DAS [6, 38], Driver Anger Indicators Scale - DAIS [40]. There is no doubt that aggressiveness in driving is a reliable indicator, even when it is viewed with some caution in the sense of socially desirable responses which are inevitable in a survey research.

Regression model III refers to the identified impact of assessed risk of driver through the DAQ survey on the occurrence of traffic accidents. It is possible to conclude that this model for traffic accident prediction does not explain a large share of the total variance of accidents which drivers from the sample experienced, although it proved to be statistically significant. This finding could be interpreted by intuitive character of items in this questionnaire which in some way suggest a research purpose to subjects, thereby increasing the likelihood of socially desirable responding. The DAQ questionnaire in other studies showed a greater 
predictive power when indicating the gender differences in the attitudes toward risk [24]. Such analysis in the observed sample is not reasonable due to the disproportionate presence of drivers of both genders in a sample of professional drivers. Some authors even used the isolated dimensions of this questionnaire, such as speeding, for the assessment of implicit attitudes towards risky driving [41]. However, DAQ questionnaire turned out to be an important instrument in predicting traffic accidents which is proven by examples in literature [24, 42].

The last analysed model IV describes the occurrence of accidents by a driver depending on the reported assessment of their own skills and competencies necessary to operate the vehicle in the Questionnaire for self-assessment of the driving ability. Other authors, for example Tronsmoen [43], obtained a more significant relation between the occurrence of accidents and scores from the questionnaire of self-assessment of driving ability; however, the sample was made up exclusively of young novice drivers whose specific driving skills play a crucial role in the traffic accidents occurrence.

When it comes to the results of binary logistic regression, where the drivers are segmented if they experienced traffic accident or not, having in mind the expression of psychological characteristics and behaviour in traffic, the proposed model shows a high predictive power. Therefore, this statistical method proves the previously considered results. It points out that the model with all the previously discussed predictors, except self-assessment of driving ability, is very effective in predicting accidents in traffic. In addition to the statistical significance of the model which certainly represents a relevant indicator of the model's strength, a high percentage of drivers with accidents are detected successfully. This analysis enabled more accurate prediction of the potential number of accidents which may be expected from the driver based on the scores in the questionnaires.

The outcome of this study is a proposal of the original models for assessing the circumstances of traffic accident occurrence on the basis of driver's personality traits related to the impulsiveness, aggressiveness, attitudes and self-assessment of personal driving abilities. The achieved results provide a possibility for defining new directions of research in the field of traffic psychology and traffic safety.

When it comes to the limitations of this study, it should be kept in mind that the results are based on the data collected by the drivers' self-reports. Such methods of data collection can lead to the distortions due to socially desirable answers. Although respondents were familiar with the anonymous nature of testing as well as guaranteed confidentiality of the collected data, it is assumed that they still had some kind of restraint in responding in relation to certain aspects of behaviour. This is particularly evident in the case of professional drivers, since it is known as a rule that this population gives socially desirable answers. Further research directions should be focused on the minimization or elimination of these limitations.

However, despite the mentioned limitations, the results of this study indicate an important role of certain personality traits in risky behaviour in traffic. These findings could find their practical applicability for different purposes. For example, based on the results of this research the criterion in the selection of professional drivers could be significantly improved. This improved selection would involve the use of instruments for assessing personality traits along with the psychomotor tests which enables more exact assessment of the driver abilities. This is particularly important for vulnerable category of young drivers who show a high rate of involvement in traffic accidents, especially at the beginning of their driving experience. On the other hand, these results may have their practical implications in the design of training and education process of candidates for a driving license. By knowing the risk factors for experiencing traffic accidents which are analysed in this study, with the understanding of preferred learning styles could improve the process of education of young drivers. Furthermore, these results are important for the development of programs for the prevention of accidents and violations of laws. Besides this, they could be used in the programs for rehabilitation of drivers who have been deprived of their driving license, as well as in the promotion of safer driving styles, according to the personality traits of the driver.

\author{
Mr MARJANA ČUBRANIĆ-DOBRODOLAC ${ }^{1}$ \\ E-mail: marjana@sf.bg.ac.rs \\ Prof. dr KRSTO LIPOVAC ${ }^{1}$ \\ E-mail: k.lipovac@sf.bg.ac.rs \\ Prof. dr SVETLANA ČIČEVIć ${ }^{1}$ \\ E-mail: s.cicevic@sf.bg.ac.rs \\ Prof. dr BORIS ANTIĆ ${ }^{1}$ \\ E-mail: b.antic@sf.bg.ac.rs \\ ${ }^{1}$ Univerzitet u Beogradu, Saobraćajni fakultet \\ Vojvode Stepe 305, 11000 Beograd, Srbija
}

\section{MODEL ZA PREDIKCIJU SAOBRAĆAJNIH NEZGODA BAZIRAN NA PROCENI OSOBINA LIČNOSTI VOZAČA}

\section{SAŽETAK}

Predloženi model u ovom radu koristi četiri psihološka instrumenta za procenu ponašanja vozača i osobina ličnosti u cilju pronalaska odnosa između razmatranih konstrukata i pojave saobraćajnih nezgoda. Korišćene su Barratt Impulsiveness Scale (BIS-11) za procenu impulsivnosti, Upitnik za procenu agresivnog ponašanja u vožnji (ADBQ), Manchester upitnik za procenu stavova vozača (DAQ) i Upitnik za samoprocenu vozačkih sposobnosti. Pored ovih instrumenata, učesnici su popunili obiman demografski upitnik. U okviru statističke analize, pored deskriptivnih indikatora, izračunati 
su koeficijenti korelacije i izvršene su četiri hijerarhijske regresione analize za određivanje prediktivne moći osobina ličnosti u nastanku saobraćajnih nezgoda. U cilju potvrde rezultata i dobijanja dodatnih informacija o odnosu između razmatranih varijabli, implementirani su Structural equation modelling (SEM) i binarna logistička regresija. Uzorak ovog istraživanja obuhvatio je 305 vozača, od kojih je bilo 100 vozača autobusa i 102 vozača kamiona, kao i 103 vozača privatnih vozila. Rezultati ukazuju na to da BIS-11 i ADBQ upitnici imaju najbolju prediktivnu moć što znači da impulsivnost $i$ agresivnost kao osobine ličnosti imaju najveći uticaj na nastanak saobraćajnih nezgoda. Ovo istraživanje može biti korisno u mnogim oblastima, kao što su procedure za selekciju profesionalnih vozača, programi za sprečavanje saobraćajnih nezgoda i kršenje propisa, rehabilitacija vozača kojima je oduzeta vozačka dozvola, itd.

\section{KLUUČNE REČI}

percepcija rizika; agresivnost; impulsivnost; samoprocena; saobraćajne nezgode; bezbednost saobraćaja;

\section{REFERENCES}

[1] Bédard M, Guyatt GH, Stones MJ, Hirdes JP. The independent contribution of driver, crash, and vehicle characteristics to driver fatalities. Accident Analysis \& Prevention. 2002;34(6): 717-727. Available from: https://doi.org/10.1016/S0001-4575(01)00072-0 [Accessed 24 th January 2017]

[2] Quimby AR. Comparing UK and European drivers on speed and speeding issues: some results from SARTRE 3 survey, in Behavioural research in Road Safety: Fifteenth Seminar. London: Department for Transport; 2005. p. 49-67. Available from: http://www.bv.transports.gouv.qc.ca/mono/0996518.pdf [Accessed 22 ${ }^{\text {nd }}$ February 2017].

[3] Sjöberg L, Wahlberg A. Risk perception and new age beliefs. Risk Analysis. 2002; 22(4): 751-764. Available from: https://doi.org/10.1111/0272-4332.00066 [Accessed 19 ${ }^{\text {th }}$ January 2017]

[4] Elvik R. Speed and road safety: Synthesis of evidence from evaluation studies. Transportation Research Record: Journal of the Transportation Research Board. 2005;1908: 59-69. Available from: https:// doi.org/10.3141/1908-08 [Accessed $17^{\text {th }}$ December 2016]

[5] Moen BE, Rundmo T. Worrying about Transport Risks. In: Rundmo T, Moen BE. (eds.) Risk Judgement and Safety in Transport. Warsaw: Swedish National Road and Transport Research Institute (VTI); 2005. p. 5-16. Available from: http://www.diva-portal.se/smash/get/ diva2:781525/FULLTEXT01.pdf [Accessed $12^{\text {th }}$ January 2017]

[6] Deffenbacher JL, Oetting ER, Lynch RS. Development of a driving anger scale. Psychological Reports. 1994;74(1): 83-91. Available from: https://doi. org/10.2466/prO.1994.74.1.83 [Accessed 24 ${ }^{\text {th }}$ December 2016]

[7] Lajunen T, Parker D, Stradling SG. Dimensions of driver anger, aggressive and highway code violations and their mediation by safety orientation. Transportation Research Part F: Traffic Psychology and Behaviour. 1998;1(2): 107-121. Available from: https://doi.
org/10.1016/S1369-8478(98)00009-6 [Accessed $24^{\text {th }}$ December 2016]

[8] Shinar D. Aggressive driving: The contribution of the drivers and the situation. Transportation Research Part F: Traffic Psychology and Behaviour. 1998;1(2): 137-160. Available from: https://doi.org/10.1016/ S1369-8478(99)00002-9 [Accessed $7^{\text {th }}$ December 2016]

[9] Hennessy DA, Wiesenthal DL. Traffic congestion, driver stress, and driver aggression. Aggressive Behavior. 1999;25(6): 409-423. Available from: https://doi.org/10.1002/(SICl)10982337(1999)25:6\%3C409::AID-AB2\%3E3.0.CO;2-0 [Accessed $19^{\text {th }}$ January 2017]

[10] Elander J, West R, French D. Behavioral correlates of individual differences in road-traffic crash risk: an examination of methods and findings. Psychological Bulletin. 1993;113(2): 279-294. Available from: https:// doi.org/10.1037/0033-2909.113.2.279 [Accessed $8^{\text {th }}$ January 2017]

[11] Underwood G, Chapman P, Wright S, Crundall D. Anger while driving. Transportation Research Part F: Traffic Psychology and Behaviour. 1999;2: 55-68. Available from: https://doi.org/10.1016/S13698478(99)00006-6 [Accessed $16^{\text {th }}$ January 2017]

[12] Sümer N. Personality and behavioral predictors of traffic accidents: testing a contextual mediated model. Accident Analysis \& Prevention. 2003;35(6): 949964. Available from: https://doi.org/10.1016/S00014575(02)00103-3 [Accessed $8^{\text {th }}$ January 2017]

[13] Herrero-Fernándeza D, Fonseca-Baeza S. Angry thoughts in Spanish drivers and their relationship with crash-related events. The mediation effect of aggressive and risky driving. Accident Analysis \& Prevention. 2017;106: 99-108. Available from: https://doi. org/10.1016/j.aap.2017.05.015 [Accessed $8^{\text {th }}$ February 2017]

[14] Stephens AN, Sullman MJ. Development of a short form of the driving anger expression inventory. Accident Analysis \& Prevention. 2014;72: 169-176. Available from: https://doi.org/10.1016/j.aap.2014.06.021 [Accessed $14^{\text {th }}$ January 2017]

[15] Clapp JD, Olsen SA, Danoff-Burg S, Hagewood JH, Hickling EJ, Hwang VS, Beck JG. Factors contributing to anxious driving behavior: The role of stress history and accident severity. Journal of Anxiety Disorders. 2011;25(4): 592-598. Available from: https://doi. org/10.1016/j.janxdis.2011.01.008 $\quad$ [Accessed $8^{\text {th }}$ January 2017]

[16] Mallia L, Lazuras L, Violani C, Lucidi F. Crash risk and aberrant driving behaviors among bus drivers: The role of personality and attitudes towards traffic safety. Accident Analysis \& Prevention. 2015;79: 145-151. Available from: https://doi.org/10.1016/j. aap.2015.03.034 [Accessed $9^{\text {th }}$ November 2016]

[17] Mohamed M, Bromfield NF. Attitudes, driving behavior, and accident involvement among young male drivers in Saudi Arabia, Transportation Research Part F: Traffic Psychology and Behaviour. 2017;47: 59-71. Available from: https://doi.org/10.1016/j.trf.2017.04.009 [Accessed $8^{\text {th }}$ January 2017]

[18] Luengo MA, Carrillo-de-la-Peña MT, Otero JM. The components of impulsiveness: a comparison of the 
17 Impulsiveness Questionnaire and the Barratt Impulsiveness Scale. Personality and Individual Differences. 1991;12(7): 657-667. Available from: https:// doi.org/10.1016/0191-8869(91)90220-6 [Accessed $25^{\text {th }}$ January 2017]

[19] PattonJH,StanfordMS, BarrattES. Factorstructure ofthe Barratt Impulsiveness Scale. Journal of Clinical Psychology. 1995;51(6): 768-774. Available from: https://doi. org/10.1002/1097-4679(199511)51:6\%3C768::AIDJCLP2270510607\%3E3.0.C0;2-1 [Accessed 26 ${ }^{\text {th }}$ February 2017]

[20] Stanford MS, Houston RJ, Mathias CW, Villemarette-Pittman NR, Helfritz LE, Conklin SM. Characterizing aggressive behaviour. Assessment. 2003;10(2): 183-190. Available from: https://doi. org/10.1177/1073191103010002009 [Accessed $8^{\text {th }}$ January 2017]

[21] Berdoulat E, Vavassori D, Muñoz Sastre MT. Driving anger, emotional and instrumental aggressiveness, and impulsiveness in the prediction of aggressive and transgressive driving. Accident Analysis \& Prevention. 2013;50: 758-767. Available from: https://doi. org/10.1016/j.aap.2012.06.029 [Accessed 14 ${ }^{\text {th }}$ January 2017]

[22] Connor DF, Steingard RJ, Anderson JJ, Melloni RH. Gender differences in reactive and proactive aggression. Child Psychiatry \& Human Development. 2003;33(4): 279-294. Available from: https://doi. org/10.1023/A:1023084112561 [Accessed $8^{\text {th }}$ February 2017]

[23] Mouloua M, Brill JC, Shirkey E. Gender differences and aggressive driving behavior: A factor analytic study. Proceedings of the 51st Annual Meeting of the Human Factors and Ergonomics Society; Baltimore, MD; 2007. p. 1283-1286.

[24] Parker D, Lajunen T, Stradling S. Attitudinal predictors of interpersonally aggressive violations on the road. Transportation Research Part F: Traffic Psychology and Behaviour. 1998;1(1): 11-24. Available from: https://doi.org/10.1016/S1369-8478(98)00002-3 [Accessed $8^{\text {th }}$ January 2017]

[25] Tronsmoen T. Associations between self-assessment of driving ability and accident risk among young drivers. Transportation Research Part F: Traffic Psychology and Behaviour. 2008;11(5): 334-346. Available from: https://doi.org/10.1016/j.trf.2008.02.002 [Accessed $16^{\text {th }}$ January 2017]

[26] Road Traffic Safety Agency of the Republic of Serbia, Trends of indicators. Belgrade: Road Traffic Safety Agency of the Republic of Serbia; 2017. Available from: http://www.abs.gov.rs/trendovi-pokazatelja [Accessed $10^{\text {th }}$ August 2017]

[27] Santos J, Lu J. Occupational safety conditions of bus drivers in metro Manila. International Journal of Occupational Safety and Ergonomics. 2016;22(4): 508513. Available from: https://doi.org/10.1080/10803 548.2016 .1151700 [Accessed $15^{\text {th }}$ January 2017]

[28] Bagozzi R, Yi Y. Specification, evaluation, and interpretation of structural equation models. Journal of the Academy of Marketing Science. 2012;40(1): 8-34. Available from: https://doi.org/10.1007/s11747-0110278-x [Accessed $5^{\text {th }}$ January 2017]

[29] Jiang K, Ling F, Feng Z, Wang K, Shao C. Why do drivers continue driving while fatigued? An application of the theory of planned behavior, Transportation Research Part A: Policy and Practice. 2017;98: 141-149. Available from: https://doi.org/10.1016/j.tra.2017.02.003 [Accessed $8^{\text {th }}$ January 2017]

[30] Jovanović D, Stanojević P, Jakšić D. The influence of risk perception and self-assessed driving abilities on the behavior of young drivers, XII International Symposium “Road Accidents Prevention 2014", 9-10 October 2014, Borsko Jezero, Serbia.

[31] Machin MA, Sankey KS. Relationships between young drivers' personality characteristics, risk perceptions, and driving behaviour. Accident Analysis \& Prevention. 2008;40: 541-547. Available from: https://doi. org/10.1016/j.aap.2007.08.010 [Accessed $8^{\text {th }}$ January 2017]

[32] Dahlen ER, Martin RC, Ragan K, Kuhlman MM. Driving anger, sensation seeking, impulsiveness, and boredom proneness in the prediction of unsafe driving. Accident Analysis \& Prevention. 2005;37(2): 341-348. Available from: https://doi.org/10.1016/j. aap.2004.10.006 [Accessed 26 ${ }^{\text {th }}$ January 2017]

[33] Ryb GE, Dischinger PC, Kufera JA, Read KM. Risk perception and impulsivity: Association with risky behaviors and substance abuse disorders. Accident Analysis \& Prevention. 2006;38(3): 567-573. Available from: https://doi.org/10.1016/j.aap.2005.12.001 [Accessed $4^{\text {th }}$ January 2017]

[34] Moan IS, Norström T, Storvoll EE. Alcohol use and drunk driving: the modifying effect of impulsivity, Journal of Studies on Alcohol and Drugs. 2013;74(1): 114-119. Available from: https://doi.org/10.15288/ jsad.2013.74.114 [Accessed $8^{\text {th }}$ January 2017]

[35] Jakubczyk A, Klimkiewicz A, Wnorowska A, Mika K, Bugaj M, Podgórska A, Barry K, Blow FC, Brower KJ, Wojnar M. Impulsivity, risky behaviors and accidents in alcohol-dependent patients. Accident Analysis \& Prevention. 2013;51: 150-155. Available from: https:// doi.org/10.1016/j.aap.2012.11.013 [Accessed 16 ${ }^{\text {th }}$ February 2017]

[36] Xu J, Li J, Jiang L. The effects of situational factors and impulsiveness on drivers' intentions to violate traffic rules: Difference of driving experience. Accident Analysis \& Prevention. 2014;62: 54-62. Available from: https://doi.org/10.1016/j.aap.2013.09.014 [Accessed $8^{\text {th }}$ January 2017]

[37] Deffenbacher JL, Huff ME, Lynch RS, Oetting ER, Salvatore NF. Characteristics and treatment of high-anger drivers. Journal of Counseling Psychology. 2000;47(1): 5-17. Available from: https://doi.org/10.1037/00220167.47.1.5 [Accessed $8^{\text {th }}$ January 2017]

[38] Dahlen ER, Edwards BD, Tubré T, Zyphur MJ, Warren CR. Taking a look behind the wheel: An investigation into the personality predictors of aggressive driving. Accident Analysis \& Prevention. 2012;45: 1-9. Available from: https://doi.org/10.1016/j.aap.2011.11.012 [Accessed $19^{\text {th }}$ January 2017]

[39] Deffenbacher JL, Lynch RS, Richards TL. Anger aggression and risky behavior: a comparison of high and low anger drivers. Behavior research and Therapy. 2003;41(6): 701-718. Available from: https://doi. org/10.1016/S0005-7967(02)00046-3 [Accessed $29^{\text {th }}$ January 2017] 
[40] Zhang H, Qu W, Ge Y, Sun X, Zhang K. Effect of personality traits, age and sex on aggressive driving: Psychometric adaptation of the Driver Aggression Indicators Scale in China. Accident Analysis \& Prevention. 2017;103: 29-36. Available from: https://doi.org/10.1016/j. aap.2017.03.016 [Accessed $4^{\text {th }}$ March 2017]

[41] Rusu A, Sârbescu P, Moza D, Stancu A. Implicit attitudes towards risky driving: Development and validation of an affect misattribution procedure for speeding. Accident Analysis \& Prevention. 2017;100: 15-22. Available from: https://doi.org/10.1016/j. aap.2016.12.022 [Accessed $8^{\text {th }}$ January 2017]

[42] Taylor MC, Lynam DA, Baruya A. The effect of drivers' speed on the frequency of road accidents. Crowthorne: TRL Limited; 2000. Available from: http://www.20splentyforus.co.uk/UsefulReports/TRLREports/trl421SpeedAccidents.pdf [Accessed 25 ${ }^{\text {th }}$ January 2017]

[43] Tronsmoen T. Associations between driver training, determinants of risky driving behaviour and crash involvement. Safety Science. 2010;48(1): 35-45. Available from: https://doi.org/10.1016/j.ssci.2009.05.001 [Accessed $24^{\text {th }}$ January 2017] 